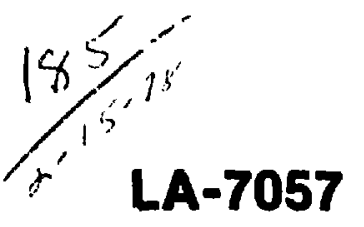

\section{A Procedure for the Analysis of Americium in Complex Matrices}

\author{
Daryi Knab
}

UC-4

\title{
MASTER
}

th. 1842

Issued: February 1978 


\title{
A PROCEDURE FOR THE ANALYSIS OF AMERICIUM IN COMPLEX NATRICES
}

\author{
by
}

Daryl Knab

\begin{abstract}
A radioanalytical procedure for the analysis of americium in complex matrices has been developed. Clean separations of americium can be obtained from up to $100 \mathrm{~g}$ of sample ash, regardless of the starting material. The at:lity to analyze large masses of material provides the increased sensitivity necessary to detect americium in Eany environmen'al samples. The procedure adequately decontaminates from rare eart $b$ elements and natural racioactive nuclides that interfere with the alpha spoctrometric measurements.

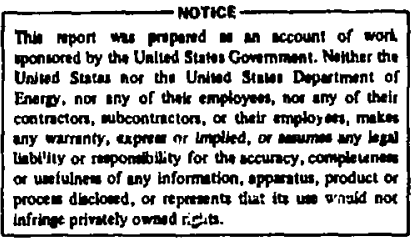

\section{INTRODUCTION}

The Environmental Studies Group at the Las Alamos Scientific Laboratory (LASL) is investigating the biogevchemical behavior of ${ }^{201} \mathrm{Am}$ in the natural environment. ${ }^{1,2}$ Analysis of americium in environmental samples is difficult because of the very low concentrations available and inherent problems of chemically isolating americiun: from complex matrices. ${ }^{2,4} \mathrm{~A}$ radiochemical procedure suitable for the simultaneous analysis of several samples for americium from large quantities of several matrices was necessary for this study. A procedure has been developed that meets these requirements and is aiso applicable to other analytical problems relative to americium. The procedure yields clean separations of americium from up to $100 \mathrm{~g}$ of sample ash, regardless of the starting material. It adequately decontaminates from rare earth elements (REE), and natural and man-made actinides and their decay products (ACT) that interfere with alpha spectrometric measurements. The procedure is designed for large samples, but can be shortened for smaller or less complex samples by omitting portions of the procedure.

The procedure is lengthy, but not esoteric or complex and is therefore suicable for simultaneous analysis of many samples. The procedure is outlined here and a detailed procedure is given in the Appendix. The extraction is insensitive to chemical conditions, th.arefore samples can be dissolved by any method suitable for the matrix being analyzed. Even the final acid dissolution before extraction is not critical, but $6 \mathrm{M} \mathrm{HCl}$ is convenient and is recommended. The initial step 
is a liquid-liquid extraction of americium into DEHPP that makes the procedure extremely versatile and selective. The extraction procedure is based on work reported by Myasoedov et il. and has been adapted for environmental aamples.' No matrix encountered has interfered with the extraction, although bones do require a more concentrated extracting solution. The plutonium anion exchange column is thc classic method for plutoniun separation. "It can be run before or after the extraction : $r$ eliminated if plutonium is not being analyzed. It is necessary that plutonium be in the correct oxidation atate for each step. The methanol-nitric acid column reported by Majors et al." is an excellent cleanup step for separating residual macromuierials including alkaline earths, other actinides, and most rare earths. Many americium samples can be plated directly after the methanol-nitric acid column. For samples with a high REE content, an additional Am-REE separation step is required. The thiocyanate anion column reported by Livingston et al. is used for this purpose. ${ }^{10}$ The resultant americium from either column is then electrodeposited before measurement by alpha apectroscopy.

\section{RESULTS}

Some rest!lts obtained from the procedure are tabulated in Table I. A Health and Safety Laboratory (HASL) soil standard is the only external standard analyzed so far. The recoveries and internal agreemert were good and accuracy relative to the reported HASL value was acceptable. The analyses results averaged about $10 \%$ high, which probably reflects calibration differences. Recoveries from routine analysis of soils and vegetation samples are adequate. The average for the 56 vegetation samples includes four samples with $<20 \%$ recovery, which is about the expected level of anomalous low recoveries for routine analysis. Bone sample recoveries reported here are unacceptable, but they reflect changes in the extraction procedure not applicable to bone sample analysis, which can be circumvented.

\section{TABLE I}

\section{AMERICIUM RESULTS}

\begin{tabular}{|c|c|c|c|c|}
\hline $\begin{array}{c}\text { Sample } \\
\text { Type }\end{array}$ & $\begin{array}{c}\text { Sample } \\
\text { Weight (B) }\end{array}$ & $\begin{array}{c}\text { Number of } \\
\text { Samples }\end{array}$ & $\begin{array}{c}\text { Recovery } \\
\text { (av \%) }\end{array}$ & $\begin{array}{c}\text { Result } \\
\text { (PCi/g) }\end{array}$ \\
\hline $\begin{array}{l}\text { HASL soil } \\
\text { standard }\end{array}$ & 50 & 2 & 90 & $\begin{array}{c}0.20 \pm 0.01 \\
(1.0)^{2}\end{array}$ \\
\hline $\begin{array}{l}\text { HASL soil } \\
\text { standard }\end{array}$ & 10 & 6 & 85 & $\begin{array}{c}0.218 \pm 0.003 \\
(1.1)^{2}\end{array}$ \\
\hline Blank soil & 100 & 4 & 83 & $0.0001 \pm 0.0003$ \\
\hline Lichen & 100 & 18 & 83 & $0.020 \pm 0.001$ \\
\hline Vegetation & $10-300$ & 56 & 65 & ... \\
\hline Bone & $50-300$ & 13 & 41 & $0.0003 \pm 0.0002$ \\
\hline
\end{tabular}

LASL value/HASL standard value. 


\section{EXTRACTION}

Figure 1 shows some detail on the extraction procedure. It uses a synergistic extractant composed of $\sim 0.045 M$ HDEHP $\cdot 0.015 M P_{2} \mathrm{O}_{8}$ in cyclohexane (0.015M DEHPP). The DEHPP extracts actinides, lanthanides (elements containing $f$ shell electrons), and radium from very strong acid solutions, even up to concentrated solutions of $\mathrm{HCl}$ and $\mathrm{HClO}_{4}$ acids. Other elements, including common matrix materials, do not extract nor do they interfere, making the method applicable to a wide variety of samples.

The DEHPP is prepared by adding $\mathrm{P}_{2} \mathrm{O}_{6}$ to bis (2-ethylhexyl) hydrogen phosphate (HDEHP) and allowing the mixture to react overnight before diluting with cyclohexane. If the $\mathrm{P}_{3} \mathrm{O}_{\mathrm{a}}$ is added to HDEHP prediluted with cyclohexane, a weaker and less consistent profluct is obtained. The stronger reagent yields quantitative extraction at lower concentrations, $0.015 M$ opposed to $0.1 M$, and gives better phase separation and less phosphate residues on decomposition of the back extract.

The extraction is aufficiently strong that back extraction is difficult, but carbonate solutions effectively back extract americium and anything else that extracts, plue $\mathrm{P}_{\mathbf{g}} \mathrm{O}_{\mathbf{b}}$ products and part of the HDEHP. A saturated solution of ammonium carbonate is recommended, although it is necessary to dilute the organic phase with ethyl acetate to effect complete back extraction. Acid decomposition of the back extract with $\mathrm{HClO}_{4}$ is neceseary to destroy residual HDEHP, which interferes with subsequent plutonium analysis. The decomposition results in insoluble phosphates that must be dissolved in $\mathrm{HF}$, and americium is then conveniently coprecipitated with YF.

Extraction of americium from large bone samples is not complete with $0.015 M$ DEHPP, although earlier studies using $0.1 M$ DEHPP gave good americium recoveries through the extraction steps from up to $100 \mathrm{~g}$ of bone ash.' Consequently, it appears that bone samples must be treated as special cases in the extraction steps. The remainder of the procedure is unchanged for bone samples. The 0.1M DEHPP for extracting americium from bone samples is prepared by adding $14 \mathrm{~g} \mathrm{P}, \mathrm{O}_{\mathrm{g}}$ to $97 \mathrm{~g}$ HDEHP dissolved in $300 \mathrm{ml}$ of cyclohexane; after stirring for $1 \mathrm{~h}$, the mixture is further diluted to $I \ell$ with cyclohexane and allowed to settle overnight.

\section{PLUTONJUM ANION EXChaNGE COLUMN}

The extraction step is highly selective, but still leaves REE, radium, ACT, and a small percentage of matrix maierial with the americium. The anion column for plutonium shown in Fig. 2 effectively removes plutonium and thorium, but is only necessary for samples requiring plutonium analysis or for samples with high actinide concentrations. In our work, very high levels of plute ium are not uncommon and plutonium analysis is almost always required. Therefore, this step is used routinely. Although the extraction is designed bar :cally for collecting americium, it is also applicable to plutonium samples whether americium analysis is required or not. The plutonium anion column is relatively insensitive to conditions, but large soil and bone samples can adversely affect the plutonium recoveries, necessitating an initial collection step. 
Diesolved sample

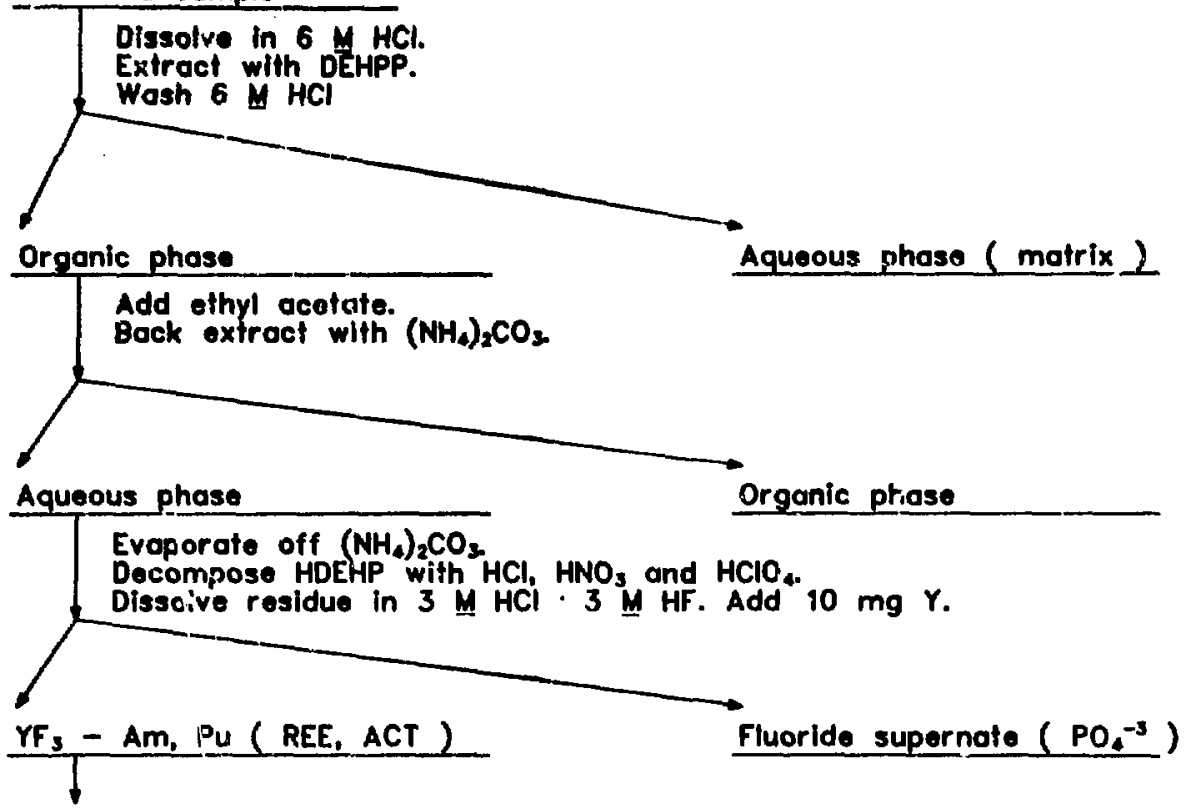

Fig. 1.

DEHPP extraction.

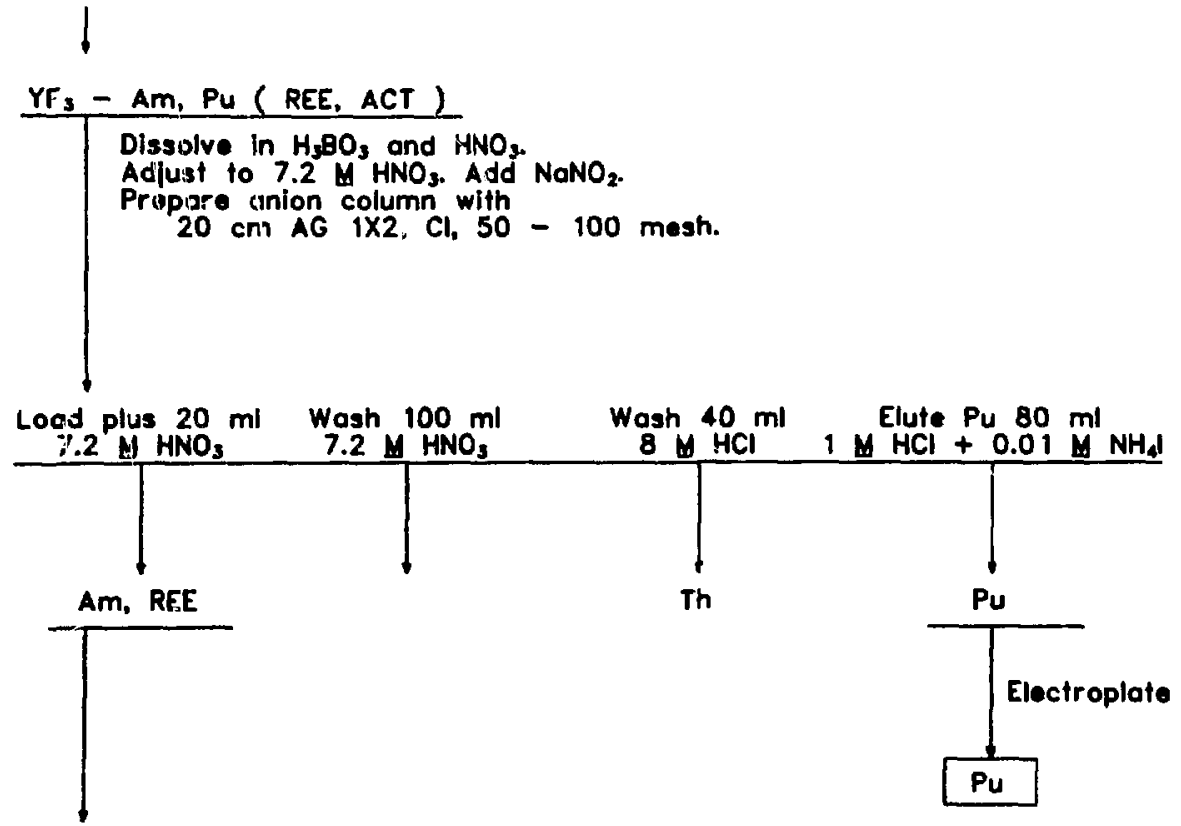

Fig. 2.

Plutonium ion excriange column. 


\section{v. METHANOL-HNO, ANION EXCHANGE COLUMN}

Additional decontamination of americium from residual matrix material, ACT, radium. and most REE is accomplished with the methanol-nitric acid anion coiumn shown in Fig. 3. Redium decontamination has been a chronic problem for environmental americium samples because some of its isciopes and their daughters interfere directly with alpha spectroscopy of americium, radium is frequently present in much higher concentrations than americium and radium thinks it is an actinide. Beirg an alkaline earth, radium should not extract, but apparentiy does and remains with americium through the entire procedure, except for the methanol-HNO, column where it is elininated effectively.

The column originally was designed as an Am-REE separation step,' but was only partially successful. Heavy rare earths, samarium to lutetium, scandium and yttrium, elute with $60 \%$ methanol $\cdot 40 \% 6 M \mathrm{HNO}_{2}$, but light rare earths, promethium to lanthanum, which account for $60 \%$ of the REE by weight, remain on the column and elute with americium in $6 M$ HNO. We found that americium can be eluted with $60 \%$ methanol - $40 \% 2.5 \mathrm{M} H \mathrm{HNO}$, leaving praesodymium, cerium, and lanthanum on the column. Neodymium tends to split under the conditions used and promethium, which has no natural abundance, has not been studied. For fission product separation, promethium undoubtedly will be a problem.

The AG MP-1 resin, an anion erchange resin available from Bjo Rad, Richmond, California, is recommended for the column. The macroporous resin alleviates the problem of slow chemical equilibration of alcohol-mineral acid solutions in ion exchange systems. Although this column will work using standard resins, the separation is improved significantly by using the MP-1 resin. Based on available data obtained from this column, it appears possible to design a system applicable for sequential elution of all the lanthanides arst actinides.

The methanol-nitric acid column also separates americium from $\mathrm{Pu}^{+4}$ and thorium. Plutonium can be eluted and plated selectively, but the column takes over $12 \mathrm{~h}$ to run through the complete procedure. The column also separates curium from americium. We assume that curium elutes ahead of americium, but this has not been verified. If ${ }^{2 \omega} \mathrm{Am}$ is being used as a tracer for curium, this column will not be useful in its present form.

Americium simples low in RES content can be plated directly after the methanol-HNO, column. The decision to plate directly or run an additional REE separation step is determined subjectively by experience. Samples containing $1 \mathrm{~g}$ of local soil yield alpha spectra that are slightly degraded, but resolvable. Thus, samples containing less than $1 \mathrm{~g}$ of soil such as tissue, bone, and small clean vegetction samples can be electrodeposited directly.

\section{THIOCYANATE ANION COLUMN}

For soil samples and samples that contain high soil content such as large vegetation samples, hides, feathers, and animal stomachs, an additional REE separation is required. The thiocyanate anion column shown in Fig. 4 yields a true group separation of REE and actinides. The REE pass through with $2 M \mathrm{SCN}^{-}$and the actinides can be eluted as a group with dilute minerai acid; radium glso elutes with the actinides. Iron and other sirongly complered metals remain on the column. It is necessary to control the $\mathrm{pH}$ of the $2 \mathrm{M} \mathrm{NH}_{4} \mathrm{SCN}$ solution. A.bove $\mathrm{pH} 5$ the REE elution: :s :etarded and below $\mathrm{pH} 2$ actinides are eluted with $\mathrm{SCN}^{-}$. Optimum separation is obtained at about $\mathrm{pH} 3$.

The main disadvantage to the column is the residual $\mathrm{SCN}^{-}$that elutes with the americium. It wist be decomposed before electrodeposition, which results in $\mathrm{H}_{2} \mathrm{SO}_{4}$ and elemental sulfur and 


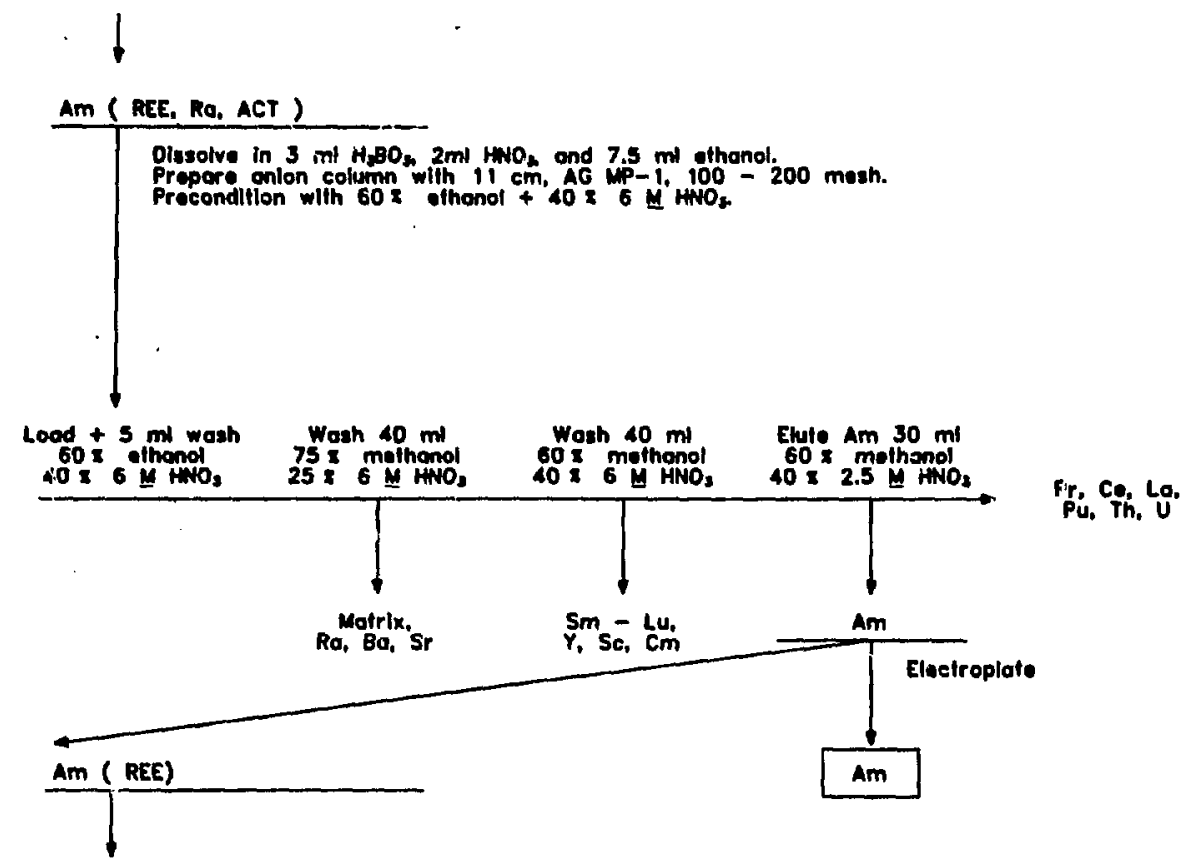

Fig. 3.

Methanol-nitric acid anion column.

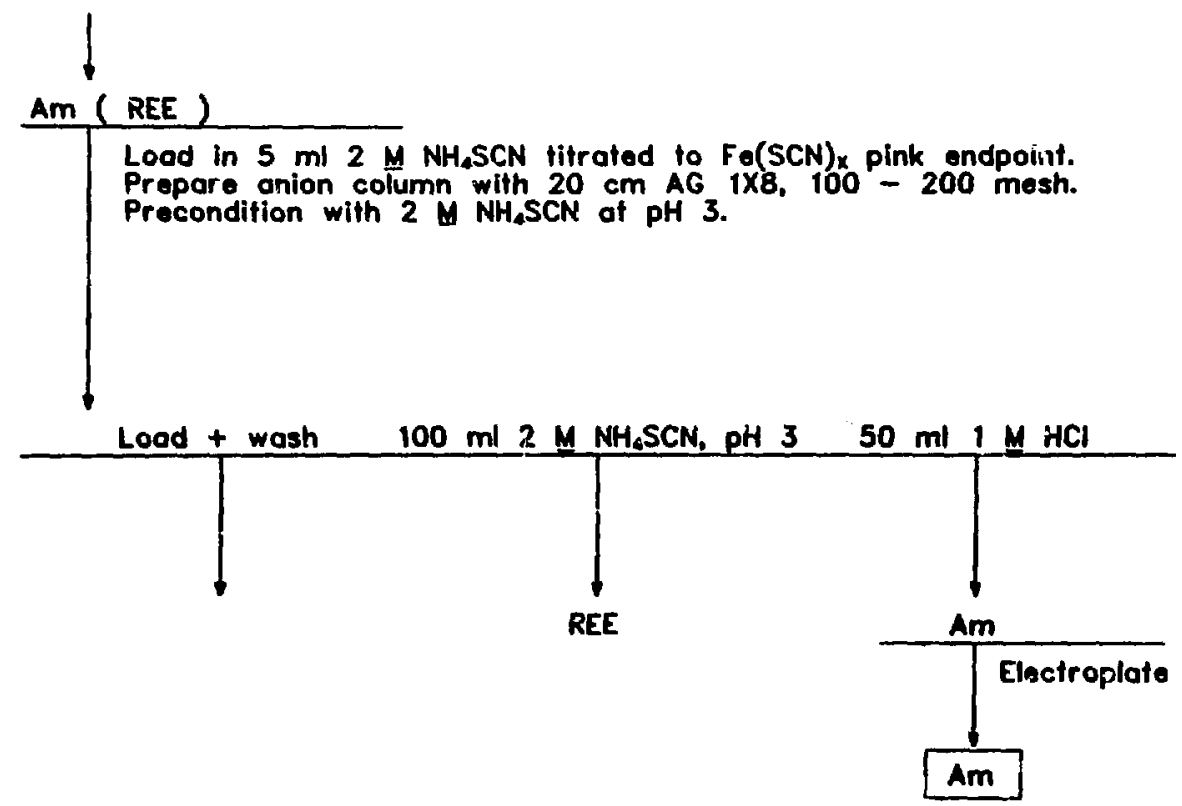

Fig. 4.

Ammonium thiocyanate anion column. 
leives a mixture difficult to work with, although the electrodeposition is not affected. Attempts to run the thiocyanate column before the methanol-nitric acid column have been unsuccessful. If the thiocyanate column is run directly after a fluoride precipitation step, the column does not run properly. Something in the fluoride precipitation or dissolution interferes with the REE elution causing them to partly load on the column and elute with the actinides. No convenient method of eliminating the interference has been found.

\section{AMERICIUM BLECTRODEPOQITION}

Electrodeposition of americium shows some interesting characteristics. A pure sample plated by a given procedure plates at a given rate. A sample passed through some chemistry plates at a slower rate with plating taking two to five times longer for complete electrodeposition. This poses some problems because it is difficult to observe. When optimizing a plating procedure, pure standards usually are used and cuntaminants are added directly to check their effect, but the slower plating rate raay not be observed. The result is devclopment data that indicate the plating procedure works very well, but may actually give low recoveries. The electroplating rate of pure standard samples passed through either anion column of this procedure is slower than for pure samples, and slower than for pure standard samples contaminated with small amounto ( $<50 \mu \mathrm{g}$ ) of material that might be present as interferences in the americium plating solution.

Plating from $\mathrm{NH}_{4} \mathrm{Cl}$ solution titrated to the methyl red end point ${ }^{12}$ is recommended over the oxalate method ${ }^{23}$ or the $\mathrm{Na}_{2} \mathrm{SO}_{4} \cdot \mathrm{NaHSO}_{4}$ method's because it is affected least and can be forced to completion. The electrodeposition is allowed to proceed at $0.6 \mathrm{~A}$ until the plating solution evaporates to the top of the anode. At some point in the evaporation, the conditions are right for quantitative deposition. It is necessary to quench and remove the sample from the plater before the solution evaporates too far. If electrical contact is broken, americium and steel are stripped from the plate.

\section{VIr. CONCLUSIONS}

The procedure is long, but not overly complex, and is quite reliable. In early stages of production, tracer recoveries were greater than $50 \%$ on more than $90 \%$ routine samples using the complete procedure. The procedure is applicable to large amounts of all matrices and adequately decontaminates americium from REE and ACT at ievels encountered in environmental samples. Currently, 24 samples are being processed simultaneously so that about 48 samples can be completed in $3 \mathrm{wk}$, requiring about $3 \mathrm{~h}$ per sample to process americium and plutonium through the complete procedure. For samples not requiring the complete procedure, cost effectiveness is improved.

\section{REFERENCES}

1. T. E. Hakonson, J. W. Nyhan, I. J. Johnson, and K. V. Bostick, "Eculogical Investigation of Radioactive Materials in Waste Discharge Areas at Los Alamos for the Period July 1, 1972, through March 31, 1973," Los Alamos Scientific Laboratory report LA-5282-MS (1973).

2. E. C. Anderson and E. M. Sullivan (compilers), "Annual Report of the Biomedical and Environmental Research Program of the LASL Health Division, January-December 1974," Los Alamos Scientific Laboratory report LA-5883-PR, pp. 46-6? (1975). 
3. H. J. Emeleus and K. W. Bagnall, Eds., Inorganic Chemistry, Series Ons, Vol. 7 (Butterworths University Park Prees, 1972).

4. K. A. Penneman and I. K. Keenen; "The Radiochemistry of Americium and Curium," National Academy of Sciences, National Reseurch Council, NAS-NS-3006 (January 1960).

5. B. F. Myasoedov, M. K. Chmutova, N. E. Kochetkova, and G. A. Pribylova, "Solvent Extraction of Trivalent Americium from Acid Media," Radiochem. Radioanal. Lett. 14, 63 (1973).

6. B. F. Myasoedov, M. K. Chmutova, N. E. Kochetkova, and G. A. Pribylova, "Extraction of Trivalent Transplutonium Elements and Europium from Highly Acidic Media," DokladyChemistry Section 213, 885 (1973).

i. D. Knab and R. J. Peters, "The Extraction of Americium and Plutonium from Environmental Samples vith HDEHP - $\mathrm{P}_{2} \mathrm{O}_{4}, "$ Abstracts of Pupers, Twentieth Conference on Analytical Chemistry in Energy and Environmental Technology, Gatlinburg, Tennessee, October 12-14, 1976, pp. 25-26.

8. G. E. Coleman, "The Radiochemistry of Plutonium," National Academy of Sciences, National Research Council, NAS-NS-3058 (September 1965).

9. W. J. Majors, K. D. Lee, and R. A. Wessman, "Analygis of "mu and ${ }^{211}$ Am from NAEG Jarge Size Bovine Samples," in The Radioecology of Plutonium and Other Tranourancis in Desert Environments, M. G. White and P. B. Dunaway, Eds., NVO-153 (1975) pp. 449-463.

10. R. Bojanowski, H. D. Livingston, D. L. Schneider, and D. R. Mann, "A Procedure for Analysis of Am in Marine Environmental Samples," Woods Hole Oceanographic Institution, C00-3563-8 (1973).

11. R. F. Mitchell, "Electrodeposition of Actinide Elements at Tracer Concentrations," Anal. Chem. 32, 326 (1960).

12. F. L. Moore and G. W. Smith, "Electrodeposition of Plutonium," Nucleonics 13, 66 (1955).

13. I. K. Kressin, "Electrodeposition of Plutonium and Americium for High Resolution a Spectrometry," Anal. Whem. 49, 842-846 (1977).

\section{APPENDIX}

\section{AMERICIUM AND PLUTONIUM FROM LARGE ENVIRONMENTAL SAMPLAS}

The procedure is suitable for all sample types containing up to $100 \mathrm{~g}$ of sample ash. The final thiocyanate column is unnecessary for amples low in rare earth elements. 
The sample dissolution method has no effect on the extraction, thus the best method for dissolving the sample matrix being analyzed is recommended.

Bone sample analysis requires a different organic extractant.

\section{DEFPP EXTRACTION PROCEDURE}

1. Add $20 \mathrm{ml} \mathrm{HCl}$ to the dissolved sample residue. Evaporate just dry. Add $200 \mathrm{ml} \mathrm{HCl}$. Boil $1 \mathrm{~h}$ to convert the sulution to $6 \mathrm{M} \mathrm{HCl}$. (If the sample is not dissolved, add additional $6 \mathrm{M} \mathrm{HCl}$ until dissolution is complete.) Let cool to room temperature. Add $10 \mathrm{~m} \ell \mathrm{H}_{2} \mathrm{O}_{2}$ and let set overnight.

2. Add $50 \mathrm{~m} \ell 0.015 M$ DEHPP (0.1M DEHPP for bone samples) to the solution. (Maintain an organic:aqueous ratio of $>1: 5$.) Stir $10 \mathrm{~min}$ on a magnetic stirrer. Pour the mixture into a separatory funnel. Let the phases separate for $10 \mathrm{~min}$ or until separation is complete. Return the aqueous phase and interface to the beaker.

3. Add $60 \mathrm{ml}$ DEHPP to the aqueous phase. Stir $5 \mathrm{~min}$. Gently pour the mixture into the separatory funnel. Let the phases separate. Drain the aqueous phase into the beaker. Retain the interface.

4. Add $100 \mathrm{ml} 6 \mathrm{M} \mathrm{HCl}$ to the organic. (Maintain an organic:aqueous ratio of $1: 1.) \mathrm{Mix} 1 \mathrm{~min}$ and let the phases separate. Drain the acid wash into the beaker.

5. Dilute the organic 1:1 with ethyl acetate, and let set $30 \mathrm{~min}$. Add $50 \mathrm{ml}$ saturated $\left(\mathrm{NH}_{4}\right)_{2} \mathrm{CO}_{2} \cdot 10 \% \mathrm{NH}_{4} \mathrm{OH}$ to the organic. (Maintain an organic:aqueous ratio of 4:1.) Carefully release the gas pressure. Shake for $3 \mathrm{~min}$. Let the phases separate. Drain the aqueous phase into a 200-me tall form beaker.

6. Add $50 \mathrm{ml}\left(\mathrm{NH}_{4}\right)_{2} \mathrm{CO}_{3} \cdot 10 \% \mathrm{NH}$ separate. If separation is slow, let set overnight. Drain the aqueous phase into the beaker. Include the interface.

7. Evaporate the solution dry on low heat. Add $20 \mathrm{ml} \mathrm{HNO}_{3}, 20 \mathrm{ml} \mathrm{HCl}$ and evaporate dry. Add $10 \mathrm{ml} \mathrm{HClO}$, and $10 \mathrm{ml} \mathrm{HNO}_{2}$. Cover and evaporate to $1 \mathrm{ml}$. Do not let the beaker dry spot.

8. Transfer the residue to a $50-\mathrm{ml}$ plastic tube with $3 M \mathrm{HCl} \cdot 3 M \mathrm{HF}$ to about $30 \mathrm{ml}$. Heat in a hot bath $10 \mathrm{~min}$. If a large precipitate remains, add $\mathrm{HF} 1 \mathrm{~m} /$ at a time and heat $10 \mathrm{~min}$ betweer additions until most of it dissolves, Add $2 \mathrm{ml} 5 \mathrm{~m} / \mathrm{NH}_{2} \mathrm{OH} \cdot \mathrm{HCl}$. Let set $10 \mathrm{~min}$.

9. Add $3 \mathrm{ml} \mathrm{HF}$. Add $5 \mathrm{mg} Y$ carrier; stir and heat $20 \mathrm{~min}$. Add $5 \mathrm{mg} Y$ carrier; stir and heat $20 \mathrm{~min}$. Cool $20 \mathrm{~min}$. Centrifuge for $5 \mathrm{~min}$. Decant off the supernate. Wash the precipitate with $25 \mathrm{~m} \ell \mathrm{M} \mathrm{HCl} \cdot 1 \mathrm{M} \mathrm{HF}$. Centrifuge and discard the wash.

10. Add $3 \mathrm{ml}$ saturated $\mathrm{H}_{2} \mathrm{BO}$. Slurry the ppt. Add $3 \mathrm{ml} \mathrm{HNO}$, and heat in a hot-water bath until the ppt dissolves. Dilute to $30 \mathrm{~m} \ell$ with $7.2 \mathrm{M} \mathrm{HNO}$. Aad $1 \mathrm{ml} 1 \mathrm{M} \mathrm{NaNO}$. Save for the plutonium anion column. Centrifuge off any insoluble jesidue before loading on the plutonium column.

\section{PLUTONIUM ION EXCHANGE SEPARATION}

1. Add $1 \mathrm{~m} \ell$ of $1 M \mathrm{NaNO}_{2}$ to the sample solution and mix thoroughly. Allow the sample to set for $1 \mathrm{~h}$.

2. Prepare anion exchange columns as follows.

(a) Pack a small glass wool plug tightiy into the tip of the ion exchange tube, filling only the tapered tip.

(b) Transfer the AG 1x2,50 - 100 mesh reein slurry to the ion exchange tube until the settled resin bec is just up to the neck of the column $(19 \mathrm{~cm}$ high by $0.7 \mathrm{~cm}$ i.d.). 
(c) Wash the resin bed with three $20-\mathrm{m} \ell$ portions of $7.2 \mathrm{M} \mathrm{HNO}_{\text {. }}$. The final wash should be done with a wash bottle making sure all resin is washed from the reservoir into the column proper. The final preconditioned column should be $13 \mathrm{~cm}$ high.

(d) Pack a glass wool plug on top of the resin to contain it.

3. Pass the sample solution through the resin column in 10-m $\mathrm{l}$ portions, allowing each: Fortion to drain to the top glass plug. Wash the tube with $5 \mathrm{ml} 7.2 M \mathrm{HNO}$, and add to the column.

4. Wash the column with $20 \mathrm{ml}$ of $7.2 \mathrm{M} \mathrm{HNO}_{2}$. Save the load solution and the $i_{2}$ at wash for the americium procedure.

5. Wash the column twice more with $50 \mathrm{ml} 7.2 \mathrm{AHNO}$.

6. Wash the column with two 20 -ml portions of $8 M \mathrm{HCl}$. Discard these washes.

7. Elute the plutonium from the column into a $100-\mathrm{ml}$ beaker with four $20-\mathrm{ml}$ portions of a freshly prepared solution containing $1 \mathrm{~g} / \ell \mathrm{NH} /$ in $1 \mathrm{M} \mathrm{HCl}$. Save for the plutonium electrodeposition procedure.

\section{PLUTONIUM ELECTRODEPOSITION PROCEDURE}

1. Add $1 \mathrm{ml} \mathrm{HNO}_{2}$ to the eluate and evaporate to dryness. (The solution may be evaporated on an asbestos-covered hotplate at low heat overnight.)

2. Add $1 \mathrm{ml} \mathrm{HNO}_{2}$ and $5 \mathrm{~m} \ell \mathrm{HCl}$ to the residue and evaporate just to dryness. (Avoid baking the sample.)

3. Add $5 \mathrm{ml} \mathrm{HCl}$ and evaporate to the first dry spots on low heat. (Avoid baking the sample.)

4. Wash down the sides of the beaker with about $5 \mathrm{ml} \mathrm{HCl}$, cover and store for at least $24 \mathrm{~h}$.

5. Evaporate the solution at medium heat just to the point at which a dry spot cannot be covered by swirling the beaker and allow the beaker to cool.

6. Add $3 \mathrm{~m} \ell$ of $4 \%\left(\mathrm{NH}_{4}\right)_{2} \mathrm{C}_{2} \mathrm{O}_{4}$ and transfer the solution to an electrodeposition cell with $0.1 \mathrm{M}$ $\mathrm{HCl}$ washes until the cell is about half full.

7. Electrodeposit for $30 \mathrm{~min}$ at $1 \mathrm{~A}$.

8. With the current on, quench the reaction by filling the cell with $1 \% \mathrm{NH}_{4} \mathrm{OH}$ solution and remove the cell irom the electrodeposition apparatus.

9. Empty the cell and rinse the planchet with water and then with ethanol.

10. Ignite the planchet to a dull red ir. the flame of a bunsen burner, allow it to cool, and store it in a labeled envelope.

\section{METHANOL-NITRIC ACID ANION COLUMN}

1. Evaporate the americium fraction from the plutonium column just dry. Add $5 \mathrm{~m} \ell 6 M \mathrm{HNO}$ and heat gently to dissolve the residue. Cover and let set.

2. Prepare the anion exchange column as followe.

(a) Pack a small glass wool plug loosely into the tip of the icn exchange tube.

(b) Transfer MP-1, 100-200 mesh resin slurry to the tube to a settled height of $11 \mathrm{~cm}$ by 0.7 cm i.d.

(c) Wash the resin with two $20-\mathrm{m} \ell$ portions of $60 \%$ ethan should be done with a wash bottle making sure all resin is washed into the coiumn tube.

(d) Cover the colunin with a watch glass to minimize alcohol evaporation.

3. After adding the lirst wash solution, add $7.5 \mathrm{ml}$ ethanol saturated with $\mathrm{NaNO}_{2}$ to the sample. Mix and transfer the sample to the column with a disposable pipet. Wash the beaker and column with $5 \mathrm{ml} 60 \%$ ethanol $\cdot 40 \% 6 M \mathrm{HNO}$, solution. 
4. Wash the column twice with $20 \mathrm{ml} 75 \%$ methanol $\cdot 25 \% 6 \mathrm{M} \mathrm{HNO}_{2}$.

5. Wash the column twice with $20 \mathrm{ml} 60 \%$ methanol - $40 \% 6 \mathrm{M}$ HNO. Diacard the load and wash solutions.

6. Elute americium with $30 \mathrm{ml} 60 \%$ methanol - $40 \% 2.6 \mathrm{M} \mathrm{HNO}_{2}$ into a 100 -ml beaker. Evaporate to $2 \mathrm{~m} \&$ on low heat.

\section{AMMONIUM THIOCYANATE ANION COLUMN}

1. Evaporate the americium fraction from the methanol column just dry. Do not bake. Add 5 $\mathrm{m} \ell \mathrm{HCl}$ and evaporate to $\sim 2 \mathrm{ml}$.

2. Prepare an ion exchange column as follows.

(a) Pack a small glass wool plug tightly into the tip of the ion exchange tube filling only the tapered tip.

(b) Transfer the AG $1 \times 8$ resin siurry to the ion exchange tube until the settled resin is $17 \mathrm{~cm}$ by $0.7 \mathrm{~cm}$ i.d.

(c) Wash the resin bed with two $25-m \ell$ portions of $2 M \mathrm{NH}_{4} \mathrm{SCN}, \mathrm{pH} 3$. The final wash should be done with a wash bottle making sure all the resin is washed into the column proper.

3. Add $2 \mathrm{ml} 6 M$ NH,SCIN to the sample. Titrate the pink Fe(SCN) $\mathrm{x}$ color to clear with dropwise addition of $\mathrm{NH}_{4} \mathrm{OH}$. Back titrate just to the pink color with $1 M \mathrm{HCl}$. Add 1 drop excess $1 \mathrm{M} \mathrm{HCl}$.

4. Load the sample on the column with a transfer pipet. Wash the tube with $10 \mathrm{ml} 2 M$ NH,SCN. Load on the column. Allow each fraction to drain down before adding the next.

5. Elute rare earths with four $25-\mathrm{ml}$ portions of $2 M \mathrm{NH}, \mathrm{SCN}$. Let eash addition drain to the plug before adding the next.

6. Elite americium into a $100-\mathrm{ml}$ beaker with two $25-\mathrm{ml}$ portions of $1 M \mathrm{HCl}$. Save for the americium electrodeposition procedure.

\section{AMERICIUM ELECTRODEPOSITION PROCEDURE}

1. Evaporate the americium fraction to dryness on low heat. Cautiously add $\mathrm{HNO}_{2}$ a little at a time until the violent reaction cesses. Add $10 \mathrm{ml} \mathrm{HNO}$, and $10 \mathrm{~m} 2 \mathrm{HCl}$. Evaporate to $1 \mathrm{ml}$. Add $10 \mathrm{ml} \mathrm{HNO}_{2}$ and $10 \mathrm{ml} \mathrm{HCl}_{2}$. Evaporate until most of the $\mathrm{H}_{2} \mathrm{SO}_{4}$ has fumed off.

2. Add $2 \mathrm{ml} \mathrm{HClO}_{4}$ to the sample. Evaporate just dry. Add $5 \mathrm{ml} \mathrm{HCl}$. Evaporate to $0.5 \mathrm{ml}$. Add $5 \mathrm{~m} \ell \mathrm{HCl}$. (Sample may be covered and stored at this point.) Eraporate to $0.5 \mathrm{ml}$. Let cool.

3. Add $2 \mathrm{ml} 4 M \mathrm{NH}_{4} \mathrm{Cl}$ and 1 drop methyl red. Titrate from red to yellow with dropwise addition of $\mathrm{NH}_{4} \mathrm{OH}$. Back titrate just to the red endpoint with $1 \mathrm{M} \mathrm{HCl}$. Transfer to a plating rell with $\mathrm{H}_{2} \mathrm{O}$ to a total volume of $8.0 \mathrm{ml}$.

4. Connect the cell to the power supply and adjust the current to $600 \mathrm{~mA}$. Plate onto a $12-\mathrm{mm}$ diam stainless steel surface until the solution in the cell evaporates to the top of the anode. Do not let the solution evaporate until contact is broken.

5. Fill the cell with $5 \% \mathrm{NH}_{4} \mathrm{OH}$ and continue plating for $30 \mathrm{~s}$. Remove the cell from the plater and rinse with $5 \% \mathrm{NH}_{4} \mathrm{OH}$ into the original beaker.

6. Dismantle the cell. Rinse the disk with $\mathrm{H}_{2} \mathrm{O}$ and then with alcohol.

7. Submit the plate for alpha spectroscopy. 
1. 0.015N DEHPP. Add $2.13 \mathrm{~g} \mathrm{P}_{3} \mathrm{O}_{3}$ to $14.5 \mathrm{~g}$ bis (2 ethylitexyl) hydrogen phosphate. Allow the mixture to react overnight. Dilute to $1 \ell$ with cyclohexane and let settle overnight.

2. 0.1M DEHPP. Dissolve $97 \mathrm{~g}$ bis (2 ethylhexyl) hydrogen phosphate in $300 \mathrm{ml}$ cyclohexane. Add $14 \mathrm{~g} \mathrm{P}_{2} \mathrm{O}_{3}$ and stir $1 \mathrm{~h}$. Dilute to $\ell$ with cyclohexane and let settle overnight.

3. Plutonium Anion Exchange Resin. AG 1x2, 50-100 mesh, $\mathrm{Cl}$ form resin is available from Bio-Rad Laboratories, Richmond, California.

4. Methanol-Nitric Acid Anion Exchange Resin. AG MP-1, 100-200 mesh resin is available from Bio-Rad Laboratories, Richmond, California.

5. Ammonium Thiocyanate Anion Exchange Resin. AG 1x8, 100-200 mesh resin is avaiiable from Bio-Rad Laboratories, Richmond, California.

5. Ammonium Thiocyanate 2M. Dissolve $1 \mathrm{lb} \mathrm{NH}_{6} \mathrm{SCN}$ in $3 \ell \mathrm{H}_{2} \mathrm{O}$. Adjust the $\mathrm{pH}$ to 3.0 with $\mathrm{HCl}$. 